\title{
Relationship between Attitude, Knowledge, and Support towards the Acceptance of Sustainable Agriculture among Contract Farmers in Malaysia
}

\author{
Azmariana Azman ${ }^{1}$, Jeffrey Lawrence D’Silva ${ }^{1}$, Bahaman Abu Samah ${ }^{1}$, Norsida Man ${ }^{2} \&$ Hayrol Azril Mohamed \\ Shaffril $^{1}$ \\ ${ }^{1}$ Institute for Social Science Studies, Universiti Putra Malaysia, Malaysia \\ ${ }^{2}$ Faculty of Agriculture, Universiti Putra Malaysia, Malaysia \\ Correspondence: Azmariana Azman, Institute for Social Science Studies, Universiti Putra Malaysia, Putra \\ Infoport, 43400 Serdang, Selangor Darul Ehsan, Malaysia. Tel: 60-3-8947-1856. E-mail: \\ majudesa.desa@gmail.com; asz_158@yahoo.com
}

Received: November 4, 2012 Accepted: November 26, 2012 Online Published: January 28, 2013

doi:10.5539/ass.v9n2p99

URL: http://dx.doi.org/10.5539/ass.v9n2p99

\begin{abstract}
Sustainable agriculture practices are known as the best techniques by which to cultivate crops. To ensure the continuity of such practices, farmers should accept and apply this method on their yield. There is an abundance of international studies which have found that attitude, knowledge and support are the main factors to impinge on the acceptance of sustainable agriculture among farmers, but studies on the same scenario are lacking for Malaysia. Filling this research gap is the main objective of this study, which seeks to elucidate the relationship between attitude, knowledge and support towards the acceptance of sustainable agriculture among contract farmers in Malaysia. This is a quantitative study, and a total of 326 respondents were involved in the data collection process. The data were gained through a developed questionnaire. The resulting analysis proves that there is a significant relationship between contract farmers' attitudes and their acceptance of sustainable agriculture $(\mathrm{r}=0.498, \mathrm{p}=0.00)$. Contract farmers' knowledge and their acceptance of sustainable agriculture are also shown to demonstrate a significant relationship $(\mathrm{r}=0.348,0.00)$. Additionally, there is support for a significant correlation between knowledge and acceptance of sustainable agriculture $(r=0.365, \mathrm{p}=0.00)$. In conclusion, farmers should have positive attitudes and adequate knowledge, and should obtain support from several parties to encourage them to embed sustainable agriculture within their farming practices.
\end{abstract}

Keywords: attitude, knowledge, support, acceptance, sustainable agriculture, contract farmers

\section{Introduction}

Malaysia is heading towards becoming a developed country. In achieving this mission, agriculture has been used as one of the catalysts. A number of efforts have been generated, nonetheless, albeit its success in developing the industry, it seems that such efforts failed to place significant impacts on farmers' socio-economic aspects particularly on their income and this is not surprising as findings of local studies have buttressed it. Shaffril et al. (2011) for example has concluded that the average income of agriculture community in Malaysia was RM669.62 (roughly equivalent to USD 220). In a study done by Terano and Mohamed (2011), farmers' income in Malaysia is still varied according to areas whereby some of them were detected to earn less than RM620 a month (roughly equivalent to USD206). Such findings are supported by recent study accomplished by Husin and Abdullah (2012), who confirmed that a total of 55\% of farmers in their study were found to earn less than RM900 a month (roughly equivalent to USD 300).

Perhaps, a new strategy in increasing farmers income is needed and involving farmers in sustainable agriculture activities is seen as a vital step as there are mounting demands on its products. Sustainable agriculture refers to technique in producing food that is healthy for humans and animals, does not threat the environment, is humane for workers, respects animals, offers good earnings for the farmer, and develops rural communities (Altieri, 1995). Government has supported sustainable agriculture projects via the establishment of Third National Agriculture Policy (TNAP), whereby it aims to produce sustainable farming by presenting integrated agriculture by concentrating on agroforestry, rehabilitation of marginal land and proper soil and water conservation. To 
achieve this, improvement on fertility of the soil shall be focused. Such effort is hugely relies on organic farming and utilization of organic matter, composting, conservation measures and production of organic fertilizers employing the existing agricultural waste in the farm (Ahmad, 2001).The establishment of TNAP has led to the emergence of a number of successful projects. One of the best examples is one conducted by Koperasi Atlet Malaysia Berhad (KAMB) and IRIS Corporation Berhad; both have cooperated in developing a model of truly communal and sustainable agricultural farming. This model is being implemented at a farm in Perak, and it is expected that the project will create "greener agriculture activities", job opportunities for locals, and high value; yield premium crops such as golden melon, cherry tomato, Japanese cucumber, eggplant, okra and habanero; and improve eco-agro tourism. This project demonstrates the ability of sustainable agriculture to improve farmers' quality of life. Nevertheless, there are several factors that affect farmers' implementation of sustainable agriculture as the implantation method. The factors that have been mentioned in past studies include contract farmers' attitudes, knowledge gained, and support obtained from their surroundings (Sadati et al., 2010; Kwadwo et al., 2008; Wheeler, 2008).

According to Sadati et al. (2010), farmers' attitudes have an impact on the acceptance of sustainable agriculture as a new technique to cultivate crops and rear livestock. Previously, Allport (1935) defined attitude as a mental readiness, ordered through long experience, and also stimulate in one direction or dynamics influence upon the individual's response to all objects with which it is related. Thus, the mean attitude of farmers depends on their mental readiness and experience in the agriculture sector. An attitude (a) refers to object, person, institution, or event; (b) has evaluative, positive or negative elements; (c) is based on cognitive beliefs towards the attitude-object; and (d) has concerns for behavior when confronted with the attitude object (Bergevoet et al., 2004).

In addition to attitude, farmers' knowledge is an important element in accepting sustainable agriculture practices. Knowledge is an essential component in development, and is extremely important in this challenging era. In the 21 st century, knowledge accretion and application will drive development processes. How can knowledge help poor farmers to increase their living standards in such a way as to reduce poverty? Knowledge can be referred to as organized or processed information or data, and is crucial in any innovation process (Kwadwo, 2008). Carreon et al. (2011) noted knowledge as one of the potential impingement factors for sustainability. Farmers can be considered as human information processing systems. Knowledge processes can be understood as the processes farmers have gone through to comprehend the information received. Such processes are categorized into two domains, namely the static domain and the dynamic domain (Carreon et al., 2011). From a knowledge perspective, we can distinguish the transition in knowledge approaches for every type of agriculture, from a conventional model to a sustainable one. The traditional model of agriculture was used prior to 1945 , when agricultural policy was basically focused on food security. Later on, this goal was altered to a scenario that accentuated profit-making. Throughout this period, the knowledge approach was driven by its main objective: to maximize productivity and profit. However, in the 1980s, as the threats of such objectives towards the environment were realized, the concept of sustainable agriculture was introduced.

In addition to farmers' attitudes and knowledge, support in terms of financial, social and educational aspects are important. Consistent support for sustainable agriculture practices in contract farming are crucial, as this will ensure its continuing viability. Not all farmers are exposed to the concept of sustainable agriculture; thus, adequate support from pertinent agencies is needed (D'Silva et al., 2010). Guo et al. (2005) and Wheeler (2008) accentuate the role of government in emboldening farmers to accept sustainable farming practices. One of the roles of government is to provide adequate financial support for sustainable farming practices. This is essential, as prior findings have revealed the importance of financial support for agriculture in terms of maximizing the socio-economic effects on rural GDP (Xiaoping and Xing, 2011).

Three factors -attitude, knowledge and support - are known as elements that drive the acceptance of sustainable agriculture. Therefore, this study aims to identify the relationship between these three factors and the acceptance of the sustainable agriculture among contract farmers in Malaysia.

\section{Methodology}

\subsection{Research Design}

This study was quantitative in nature whereby it used developed instrument to gain the required data.

\subsection{Instruments Development}

As there are no established or specific instruments in measuring contract farmers acceptance, knowledge, support and attitude, researchers have decided to constructs their own instrument which is hugely based from the 
previous studies and review of literatures. A total of 14 questions relating to contract farmers' attitude, 14 questions on sustainable agriculture knowledge, and 14 questions regarding support were included in the questionnaire. For each of the question asked, the respondents were given an option of five likert scale which ranges from 1 represents strongly disagree, 2 represents disagree, 3 represents moderately agree, 4 represents agree and 5 represents strongly agree.

\subsection{Pre-Test}

After successfully constructed the instrument, it was then pre tested among 30 contract farmers at Cameron Highland, Pahang, which resulted in the Cronbach Alpha value of .77 which exceeded the recommended Cronbach Alpha value of .70 suggested by Nunally (1978). The developed instrument then was used for the real data collection process.

\subsection{Data Collection}

The data collection process took place at Kedah, Terengganu, Selangor and Sabah. Overall the data collection took 7 months (started from May 2011 till November 2011) to be completed. A simple random sampling procedure was used to select the respondents. In this study, 326 contract farmers served as the respondents. To expedite the data collection process, assistance was given by a Federal Agriculture Marketing Authority officer. The data collection process employed trained enumerators, and the average time taken to complete the questionnaire was 20-30 minutes.

\subsection{Analysis}

For the purpose of analysis, SPSS was employed. Descriptive analyses such as frequency, percentage, mean, standard deviation were employed to clarify the general data of the study. In addition, to fulfill the objective of identifying any relationship that might occur between acceptances towards sustainable agriculture with selected independent variables, inferential analysis (Pearson product-moment correlation) was applied.

\section{Results and Discussion}

\subsection{Demographic Data}

Table 1 demonstrates the demographic data of the respondents studied. It seems that Malaysia are still having inadequate number of young farmers as there were only $9.8 \%$ of the respondents were age 30 years old and below. Majority of the respondents were included in the group age of 41-50 years old (27.9\%) and 51-60 years old $(27.0 \%)$. A huge majority of the respondents were Malay $(73.0 \%)$ and most of them were male $(69.9 \%)$. Gidarakou (1997) has found that commitment towards family and physical demand of agriculture that resulted in less involvement from female in agriculture industry. This study had quite equal distribution of respondents according their areas. Not too many of them were achieving a higher education level as only one of them was detected to have a Degree and the other four were detected to have Diploma. Majority of them were detected to possess only primary school level of education and SPM/SPMV certificates (68.1). Such scenario is not surprising as Man (2008) in her study has accentuated on the hesitance of educated persons in agriculture industry due to their perception that agriculture in only a 'second class job'. The mean score recorded for income $(\mathrm{M}=\mathrm{RM} 1,521.93)$ have reflected that most of the respondents possess a stabile income, nevertheless, it is quite concerning that a total of $39.6 \%$ of the them were detected to earn below RM500 a month which is below the poverty level of RM720 a month set by Malaysia Economic Planning Unit (EPU). Majority of the respondents were considered as 'junior' in contract farming as $43.7 \%$ of them were having $1-3$ years of experience as contract farmers (Table 1).

Table 1. Demographic data of the respondents studied

\begin{tabular}{llll}
\hline Factors & Frequency & Percentage & Mean \\
\hline Age (years) & 32 & $\mathbf{4 9 . 5}$ \\
$20-30$ & 45 & 9.8 \\
$31-40$ & 91 & 13.8 \\
$41-50$ & 88 & 27.9 \\
$51-60$ & 70 & 27.0 & \\
$>60$ & & 21.5
\end{tabular}




\section{Gender}

Male

Female

98

Zone

Northern

85

East Coast

80

Southern

Sabah/Sarawak

81

Races

Malay

Dusun

Chinese

8

\section{Level of Education}

Never been to school

Primary school

PMR/SRP

SPM/SPMV

82

Skill certificates/STPM

10

Diploma

Degree/Master

0.3

Income per month

$<$ RM500

RM501-RM1000

Experience as contract farmers (years) $(n=$ 324)

$1-3$
$4-6$
$7-10$
$11-15$
716

3.2 Factors Studied

15.7

Table 2 demonstrates the overall mean score of each of the factor studied. To gain the overall mean score, the mean summated score of each factor was gained (mean score of all questions/number of questions). To gain a detail description of the data gained, the resulted mean score then was divided into three categories namely low (mean score ranges from 1.00 to 2.33), moderate (mean score ranges from 2.34 to 3.67 ) and high (mean score ranges from 3.68 to 5.00 ). The categories were gained simply by using the formula (maximum mean score/number of categories $=5.00 / 3$ ).

Results gained have demonstrated that acceptance recorded the highest mean score with 4.25 and comparatively attitude was detected to record the lowest mean score $(M=3.74)$. In addition, knowledge and support recorded quite a high overall mean score with 4.09 and 3.88 respectively. Interestingly, analysis employed has confirmed that none of the respondents recorded a low level of mean score in term of knowledge on sustainable agriculture, hence it reflects the possibility that most of the respondents surveyed are among knowledgeable farmers with regard to sustainable agriculture. In general, majority of the respondents were found to record a high level of mean score in acceptance (88.0\%), knowledge (78.5\%), support (69.6\%) and attitude (58.6\%). 
Table 2. Factors studied

\begin{tabular}{lllll}
\hline Factors & Frequency & Percentage & Mean & Standard deviation \\
\hline Acceptance & & & $\mathbf{4 . 2 5}$ & $\mathbf{. 5 3 7}$ \\
Low $(1.00-2.33)$ & 4 & 1.3 & & \\
Moderate $(2.34-3.67)$ & 35 & 10.7 & & \\
High $(3.68-5.00)$ & 287 & 88.0 & $\mathbf{4 . 0 9}$ & $\mathbf{. 5 3 4}$ \\
Knowledge & & & & \\
Low $(1.00-2.33)$ & - & - & & \\
Moderate $(2.34-3.67)$ & 70 & 21.5 & & \\
High $(3.68-5.00)$ & 256 & 78.5 & $\mathbf{3 . 8 8}$ & \\
Support & & & & \\
Low $(1.00-2.33)$ & 4 & 1.2 & & \\
Moderate $(2.34-3.67)$ & 95 & 29.1 & & \\
High $(3.68-5.00)$ & 227 & 69.6 & $\mathbf{3 . 7 4}$ \\
Attitude & & 4.9 & & \\
Low $(1.00-2.33)$ & 16 & 36.5 & & \\
Moderate $(2.34-3.67)$ & 119 & 58.6 & & \\
High $(3.68-5.00)$ & 191 & & & \\
\hline
\end{tabular}

3.3 Relationship between Acceptance and Attitude, Knowledge and Support

The main purpose of this study is to look at the relationship between attitudes of contract farmers and their acceptance of sustainable agriculture practices. Based on the results, there is a significant correlation between attitude and acceptance $(\mathrm{r}=0.498, \mathrm{p}=0.00)$. Farmers who have good or positive attitudes towards crops are more open to accepting sustainable agriculture practices because they already cultivate crops using safe techniques to avoid any harm coming to their crops or themselves. This finding is supported by Sadati et al. (2010), who found attitude to be an important element for constructing acceptance of sustainable agriculture.

In addition, there is a positive relationship between contract farmers' knowledge and their acceptance of sustainable agriculture practices $(r=0.348,0.00)$. Knowledge is one of the major factors contributing to the recognition of sustainable agriculture; it is the key with respect to implementation and could improve sustainable practices and improve farmers' attitudes (Khoram et al., 2006). With adequate knowledge, contract farmers can apply good agriculture practices in their cultivation of crops (Azman et al., 2012). They can also obtain information about sustainable agriculture from the mass media, extension agents, their colleagues, etc.

Other than attitude and knowledge, support also has a significant relationship with the acceptance of sustainable agriculture $(\mathrm{r}=0.365, \mathrm{p}=0.00)$. Farmers need support from concerned parties such as government, financial institutions, family and friends so as to encourage them to implement sustainable agriculture practices in their cultivation of crops. The government can promote the benefits of sustainable agriculture products to society in order to encourage farmers to produce more sustainable products. Family and friends can also influence farmers to apply sustainable agriculture techniques.

As Table 3 shows, there is also a significant relationship between each independent variable, and a significant correlation between attitude and knowledge of contract $(\mathrm{r}=0.215, \mathrm{p}=0.00)$. By the same token, attitude and support have a positive correlation $(r=0.304, p=0.00)$, as do knowledge and support $(r=0.391, p=0.00)$. To form a good attitude, farmers need enough knowledge and experience because this will enable them to understand concepts and change their attitudes. Support obtained will make farmers feel more positively towards sustainable agriculture. 
Table 3. Relationship between attitude, knowledge, support and acceptance towards sustainable agriculture

\begin{tabular}{lllrrrrrrr}
\hline \multirow{2}{*}{ Variables } & \multicolumn{2}{c}{ Acceptance } & \multicolumn{2}{c}{ Attitude } & \multicolumn{2}{c}{ Knowledge } & \multicolumn{2}{c}{ Support } \\
\cline { 2 - 10 } & \multicolumn{1}{c}{$\mathbf{r}$} & $\mathbf{p}$ & $\mathbf{r}$ & $\mathbf{p}$ & $\mathbf{r}$ & $\mathbf{p}$ & $\mathbf{r}$ & \multicolumn{1}{c}{$\mathbf{p}$} \\
\hline Acceptance & 1 & - & 0.498 & 0.000 & 0.348 & 0.000 & 0.365 & 0.000 \\
Attitude & 0.498 & 0.000 & 1 & - & 0.215 & 0.000 & 0.304 & 0.00 \\
Knowledge & 0.348 & 0.000 & 0.215 & 0.000 & 1 & - & 0.391 & 0.00 \\
Support & 0.365 & 0.000 & 0.304 & 0.00 & 0.391 & 0.00 & 1 & - \\
\hline
\end{tabular}

4. Conclusion and Recommendations

Based on the results obtained, it can be concluded that farmers' attitudes, knowledge and support all have consequences on their acceptance of sustainable agriculture practices. If farmers have positive attitudes towards their surroundings and care about the environment, they will reduce their usage of pesticides, use organic manure rather than chemical fertilizers, and consider soil fertility. In other words, they will use good agriculture practices Knowledge enables farmers to understand how to apply good agriculture practices. Without enough knowledge, they will not know what to do. In order to provide knowledge to farmers, extension agents play a vital role in terms of dispensing information; the mass media is also needed in this regard. In addition, the government can carry out courses or workshops so as to provide information and teach good techniques to farmers. Contract farmers also need support from people around them. Families and friends, as the closest people to farmers, can provide moral support and encourage farmers to apply sustainable agriculture practices. The government can also help by encouraging society to use or eat healthy and chemical-free foods. Further research on sustainable agriculture, not only on cultivation techniques but also on economic and social impacts, should be conducted.

\section{References}

Ahmad, F. (2001). Sustainable agriculture systems in Malaysia. Paper presented at Regional Workshop on Integrated Plant Nutrition System (IPNS), Development in Rural Poverty Alleviation, 18-20 September 2001, United Nations Conference Complex, Bangkok, Thailand.

Allport, G. W. (1935). Attitudes. In C. Murchison (Ed.), Handbook of Social Psychology. Worcester, MA: Clark University Press.

Altieri, M. A. (1995). Agroecology: The science of sustainable agriculture. Westview Press, Boulder, CO.

Azman, A., D’Silva, J. L., Samah, B. A., Man, N., \& Shaffril, H. A. M. (2012). Comparative study on sustainable agriculture knowledge among Malaysian contract farmers. American Journal of Applied Science, 9(5), 673-67. http://dx.doi.org/10.3844/ajassp.2012.673.677

Bergevoet, R. H. M., Ondersteijn, C. J. M., Saatkamp, H. W., Woerkum, C. M. J., \& Huirne, R. B. M. (2004). Entrepreneurial behavior of dutch dairy farmers under a milk quota system: Goals, objectives and attitudes. Agriculture System, 80, 1-21. http://dx.doi.org/10.1016/j.agsy.2003.05.001.

Carreón, J. R., René, J. J., Niels, F., \& Rob, V. H. (2011). A Knowledge Approach to Sustainable Agriculture. Retrieved from http://www.springer.com/978-94-007-0889-1

D'Silva, J. A., Samah, B. A., Uli, J., \& Shaffril, H. A. M. (2011), Towards developing a framework on acceptance of sustainable agriculture among contract farming entrepreneurs. African Journal of Business Management, 5(20), 8110-8116.

Gidarakou, I. (1997). Young women's attitudes towards agriculture and women's new roles in the Greek countryside: A first approach. Journal of Rural Studies, 15(2), 147-158. http://dx.doi.org/10.1016/S0743-0167(98)00054-0.

Guo, H., Jolly, R. W., \& Zhu, J. (2005). Contract Farming in China: Supply Chain or Ball Chain? Paper presented at Minnesota International Economic Development Conference, University of Minnesota, April 29-30.

Husin, F., \& Abdullah, H. (2012). The role of FELDA and KESEDAR in the development of land in the district of Gua Musang: a comparison the socio-economic level of the settlers. Sustainable Agriculture Research, 1(2), 285-291.

Khoram, M. R., Shariat, M., Azar, A., Moharamnejad, N., \& Mahjub, H. (2006). Survey on knowledge, attitude 
and practice on sustainable agriculture among rural farmers in Hamadan Province, Iran. Sarhad Journal of Agriculture, 22(4), 701-706.

Kwadwo, A., Kristin, D., \& Dejene, A. (2008). Advancing Agriculture in Developing Countries through Knowledge and Innovation. Retrieved from http://www.ifpri.org/sites/default/files/publications/oc59.pdf

Man, N. (2008). Youth perception towards agriculture and needs on agriculture education. Journal of Malaysian Youth Development, 1, 99-114.

Newell, A., \& Simon, H. (1972). Human Problem Solving. Englewood Cliffs, NJ: Prentice Hall.

Nunnally, J. C. (1978). Psychometric theory (2nd ed.). New York: Mc-Graw Hill.

Sadati, S. A., Hosain, S. F., Ali, A., \& Sadati, S. A. (2010). Farmer's attitude on sustainable agriculture and its determinants: a case study inBehbahan County of Iran. Research Journal of Applied Sciences, Engineering and Technology, 2(5), 422-427.

Shaffril, H. A. M., Abu Samah, B., D'Silva, J., \& Uli, J. (2011). Global warming at the East Coast Zone of Peninsular Malaysia. American Journal of Agriculture and Biological Sciences, 6(3), 377-383. http://dx.doi.org/10.3844/ajabssp.2011.377.383

Terano, R., \& Mohamed, Z. (2011). Household income structure among paddy farmers in granary areas of Malaysia. Proceeding of International Conference on Innovation, Management and Service (pp. 160-165).

Wheeler, S. A. (2008). The barriers to further adoption of organic farming and genetic engineering in Australia: Views of agricultural professionals and their information sources. Renewable Agriculture and Food System, 23, 161-170. http://dx.doi.org/10.1017/S1742170507002128.

Xiaoping, H., \& Xing, Y. (2011). Economic Effects of Financial and FiscalSupport for Agriculture in Western China, present paper on $28^{\text {th }}$ International Conference of Agricultural Economists. The Global Bio Economy, $18-24$.

\section{Notes}

Note1. SPM/SPMV refers to Malaysia Education Certificate/Malaysia Vocational Certificate.

Note2. PMR/SRP refers to Malaysian Lower Education Certificate. 